\title{
A Study to Investigate the Relationship between the Perfectionist Level and Self -Esteem Level of Academicians Working at Universities
}

\begin{abstract}
Anıl GÖRKEM*
Abstract. The main purpose of this study is to examine the relationship between the perfectionism levels of academicians working at universities and their selfesteem. In addition, it was aimed to examine whether the perfectionism and selfesteem of the academicians working at the university differ in terms of variables related to gender, faculty, and duration of study, academic title and marital status. In the research, relational scanning model, one of the quantitative research methods, was used. The study, which included the typical case sampling method from purposeful sampling, was carried out in the 2018-2019 academic year with a total of 125 study groups consisting of 73 female and 52 male academicians working at universities in the Turkish Republic of Northern Cyprus. The "APS Perfectionism Scale" was used to determine the perfectionism levels of academicians working at universities, and the "Rosenberg Self-Esteem Scale" was used to determine the self-esteem levels. In order to evaluate the independent variables, a "Personal Information Form" prepared by the researcher was created and information about the variables was collected accordingly. The data were sent to all full-time academicians of the five oldest universities in the Turkish Republic of Northern Cyprus via e-mail, and the data were collected voluntarily by asking them to be answered and returned to the researcher. Correlation analysis was used to analyze the data. According to the results of correlation analysis, it was revealed that there was no relationship between the perfectionism levels of academicians working at universities and their self-esteem levels.
\end{abstract}

Keywords: Perfectionism, Self Esteem, Academic staff.

\footnotetext{
* Orcid ID: https://orcid.org/0000-0003-1532-1360, Assist. Prof. Dr., European University of Lefke, Guidance and Psychological Counseling Department, Turkish Republic of Northern Cyprus, asayilir@eul.edu.tr

Görkem, A. (2020). A study to investigate the relationship between the perfectionist level and self-esteem level of academicians working at universities, Sakarya University Journal of Education, 10(2), 212-225. doi: https://doi.org/10.19126/suje.590357
} 


\section{INTRODUCTION}

One of the first concepts that come to mind when it comes to academics is the university teacher. The definition of academic is someone that is considered to be scholar. So this professional tite is given to the educated people that provide education and training in universities and in other similar instiutitons. Academics also are trained specialists who contribute to science by doing many researches in their fields. Teaching is an inevitable fact that requires an accomplishment of personality traits such as self-esteem besides knowing teaching skills. In this regard the personality traits of academics does really matter.

In order to explain the concept of self esteem it is necessary to define what the self is. Self can be defined as an individual who is aware of his/her own existence. It is stated that the individual knows the strengths and weaknesses of his own interests, skills, and traits that he creates his own self. Self-esteem can be defined as the individual knowing himself, accepting himself, and expressing his holistic feelings (Leory, 1996). Therefore, it is seen that self-esteem consists of many concepts. People with high self-esteem (who have positive self-esteem) are also conscious that they should not go for themselves to be perfect in the neurotic dimension because they think they are talented, successful, valuable and important (Salami, 2010).

It is possible to evaluate self-esteem as positive and negative according to its level. When looking at the characteristics of people with negative self-esteem, it is stated that they exhibit depressive behaviors and those with high self-esteem are high in self-confidence, less depressed, and are more capable of coping with negative emotions easily (Yelsma \& Yelsma, 1998; Kassin, 1998). Therefore, having more or less self-esteem can be harmful or dangerous.

Perfectionism, which has an important place in self-esteem, is also a point to be examined. Perfectionism can be defined as increasing the level of ability of people by spending effort above the performance they can do. When we look at the literature, it can be said that many definitions and approaches of perfectionism are included. While Frost, Marten, Lahart and Rosenblate (1990) define the characteristics of people with high levels of perfectionism by setting standards above their performance and approaching them with extreme criticism, perfectionism has a multi-dimensional structure according to Hamachek (1978). These can produce positive and negative results.

While perfectionism can lead to success when used with high standards (Bieling, Israeli, Smith \& Antony, 2003), it can have negative consequences when used critically. It can be said that self-self comes first. Considering its positive perfectionist characteristics, it consits of people who are accepted, who love and loved by the society and have high communication skills (Flett, Hewitt, Blankstein \& Gray. 1998). Its negative features can bring many neurotic disorders along with its obsessive-compulsive disorders (Hamachek, 1978).

Therefore, when self-esteem and perfectionism are used in a positive way, it is seen that they can both be parallel. It can be said that an individual with positive self-esteem is used 
in a positive way in perfectionism. People with negative or low self-esteem are reported to use perfectionism negatively (Flett et al., 1998).

In line with all these literature, self-esteem levels and perfectionist levels of academicians, who work in higher education and particularly educate specialists, were considered to be important and it was determined that there is an important subject to be investigated by the researcher. Considering many studies, there are studies on self-esteem and perfectionism on prospective teachers (Abbasoğlu \& Öncü, 2013; Aslan \& Akyol, 2006; Circır, 2006; Tuncer \& Voltan-Acar, 2006). The fact that the subject is not studied together is thought to add importance to the research.

Accordingly, the main aim of the study is to investigate the relationship between the perfectionist and self-esteem levels of academicians working in universities. In addition, it is aimed to examine the perfectionism and self-esteem of academicians working at the university in terms of variables related to gender, faculty, working time, academic title and marital status.

\section{METHOD}

This section includes information about the research model and data collection tools.

\section{Research Model}

In this research, relational screening model, which is one of the quantitative research methods, was used. Quantitative research methods are methods that produce generalizable results, make comparisons between different groups and benefit from examining the relationships within a certain structure (Büyüköztürk, Çakmak, Akgün, Karadeniz \& Demirel., 2017). Typical case sampling method was used from purposive sampling. Typical case sampling method, which is a type of purposeful sampling, is the type of sampling that is related to the research problem and created with one typical of the situations in the universe (Karasar, 2002).

\section{Resarch Group}

The study consists of 73 female and 52 male academicians working in five universities in the Turkish Republic of Northern Cyprus (TRNC) in the 2018-2019 academic year. The responses of academics who gave feedback on the basis of volunteering were evaluated and a working group with a total number of 125 participants was formed.

\section{Collection Data Tools}

As data collection tools, Rosenberg Self-Esteem Scale, APS Perfectionism Scale and the information form which was prepared by the researcher herself were used.

\section{Rosenberg Self-Esteem Scale}

The Self-esteem Scale was prepared to measure the value and importance that individuals attach to their selfies based on their own opinion. The scale, which includes five positive and five negative items, is rated with a four-point Likert type. Since the scale is an adaptation scale, it was first adapted by Çuhadaroğlu in 1986 and later by Tuğrul in 1994. 
Cronbach alpha reliability coefficient. The test-retest Cronbach alpha reliability coefficient was found to be .71 as 76 (Çuhadaroğlu, 1986 act. Korkmaz, 1996).

In this study, Rosenberg Self-Esteem Scale Short Form (1965) was used as total score. Cronbach alpha value of the reliability coefficient of the Short Form Scale was found to be .85. The high score obtained from the scale after reversing the five negative items of the scale indicates high self-esteem.

\section{The APS Perfectionist Scale}

The APS Perfectionist Scale was developed by Slaney and Janson in 1992. It was revised by Slaney et al. In 1996 and 2001, and finalized (Slaney, Ashby, 1996, Slaney, Rice, Mobley, Trippi \& Ashby, 2001). Adapted to. APS Perfectionist Scale is a 7-point Likert-type scale developed to distinguish between compatible and incompatible features. After the scope was validated, the KMO value of which the structure was validated was found to be .87 as the sample suitability coefficient. The scale, which is based on four sub-dimensions, can be evaluated in terms of standards, Order, Unsatisfied and Conflict. The overall reliability coefficient for the reliability study was found to be 79 (Sapmaz, 2006).

\section{Information Form}

The information form was prepared by the researcher. In this information form variables that may be related to the research subject are included. These variables are; questions about the participant's age, gender, marital status, academic title, faculty, and how many years he has been working as an academician are included.

\section{Data analysis}

Before the application, five oldest universities in TRNC were selected to represent the sample, and the e-mail addresses of the academicians who are working full-time were taken from the university page and information about the study was sent to the academicians. The academics who agreed to participate in the study were asked to fill in the personal information form and scales in the e-mail attachment and send it to the researcher. It has been stated that the personal information in the study will be kept confidential and will not be shared with anyone else by the researcher. It was stated to the participants that the general study results will be used for the purpose of the research. All of the collected data were entered into the computer with SPSS 18.0 program and evaluated by making necessary analyzes. Pearson Product Moment Correlation analysis was used to analyze the relationship between academic self-esteem and perfectionism. Independent group t-test was used to determine whether self-esteem and perfectionism scores differ according to gender, variable, one-way Anova and Kuruskal Wallis test to determine whether they differ according to department, academic title, working time, faculty and marital status variables. 


\section{FINDINGS}

In this section, the findings regarding the relationship between the perfectionism and selfesteem of academicians are presented. However, there are also analyzes on whether or not differentiates in terms of some variables.

\section{Demographic Information of the Participants}

Demographic information of the participants is given in this section. Table 1 contains information about the participants' gender, marital status, academic title, faculty studied, age and working time.

Table 1

Demographic Information of the Participants

\begin{tabular}{|c|c|c|c|}
\hline Variables & & Frequency(f) & Percentiles (\%) \\
\hline \multirow{2}{*}{ Gender } & Woman & 73 & 58 \\
\hline & Man & 52 & 42 \\
\hline \multirow{4}{*}{ Marital status } & Merried & 65 & 52 \\
\hline & Single & 56 & 45 \\
\hline & Divorced & 4 & 3 \\
\hline & Doctor & 14 & 11 \\
\hline \multirow{3}{*}{ Academic title } & Assistant professor & 54 & 43 \\
\hline & Associate professor & 36 & 29 \\
\hline & Professor & 21 & 17 \\
\hline \multirow{6}{*}{$\begin{array}{l}\text { Faculty of } \\
\text { employment }\end{array}$} & $\begin{array}{l}\text { Faculty of } \\
\text { Education }\end{array}$ & 45 & 36 \\
\hline & Faculty of Law & 4 & 3 \\
\hline & $\begin{array}{l}\text { Faculty of Science } \\
\text { and Literature }\end{array}$ & 3 & 2 \\
\hline & $\begin{array}{l}\text { Faculty of } \\
\text { Architecture }\end{array}$ & 7 & 6 \\
\hline & Engineering Faculty & 9 & 7 \\
\hline & $\begin{array}{l}\text { Faculty of Health } \\
\text { Sciences }\end{array}$ & 27 & 22 \\
\hline
\end{tabular}




\begin{tabular}{|c|c|c|c|}
\hline & $\begin{array}{l}\text { Communication } \\
\text { faculty }\end{array}$ & 6 & 5 \\
\hline & $\begin{array}{l}\text { Faculty of } \\
\text { Economics and } \\
\text { Administrative } \\
\text { Sciences }\end{array}$ & 12 & 10 \\
\hline & $\begin{array}{l}\text { Faculty of } \\
\text { Agriculture }\end{array}$ & 7 & 6 \\
\hline & Faculty of Theology & 5 & 4 \\
\hline \multirow{4}{*}{ Working Time } & $1-5$ years & 54 & 43 \\
\hline & $6-10$ years & 36 & 29 \\
\hline & $11-20$ years & 21 & 17 \\
\hline & 21 years and over & 14 & 11 \\
\hline \multirow{3}{*}{ Age } & $18-30$ & 17 & 14 \\
\hline & $31-45$ & 83 & 66 \\
\hline & 46 and over & 25 & 20 \\
\hline
\end{tabular}

As stated in Table 1, it is seen that most of the participants are women ( $n=73)$, academics between the ages of 31-45 are the majority, and more than half of the academics are married and majorty of the academics involved in this study have the title of assistant professor. It has been stated that most of the participants are from the faculty of education and have been working at their universities for 1-5 years.

\section{Findings Related to the Relationship Between Self-Esteem and Perfectionist Levels of Academicians Working at the University}

Correlation analysis was carried out in order to determine the relationship between selfesteem and perfectionism levels of academicians, which is the main purpose of the research. Normality test was performed to test the necessary assumptions before correlation analysis. To test whether the total variable data provides the norm distribution assumption at .05 significance level, normality assumption was checked with the skewness coefficient value and the absolute value is less than 1.96 when the division value in the Decriptive table is divided by its standard error value (Bursal This distribution provided the normal distribution condition at .05 significance level.

In order to measure the relationship between the Self-Esteem of the Academicians and Perfectionism Levels, the Pearson correlation coefficient was calculated and for the Pearson correlation coefficient $(r=-.035 ; \mathrm{n}=125 ; \mathrm{p}=.69)$ between the Self-Esteem and the Perfectionism Levels total score in Table 2. Since the calculated significance value was 
$\mathrm{p}>.05$, it was found that there was no significant relationship between the Self-Esteem of the academics and the Perfectionism Levels (Table 2).

Table2

Pearson Correlation Analysis of the Relationship Between Academicians' Self-Esteem and Perfectionism Levels

\begin{tabular}{lccc}
\hline Variables & $\mathrm{N}$ & $\mathrm{r}$ & $\mathrm{p}$ \\
\hline $\begin{array}{l}\text { Perfectionism total } \\
\text { score }\end{array}$ & 125 & & \\
$\begin{array}{l}\text { Self-esteem total } \\
\text { score }\end{array}$ & 125 & -.035 & .69 \\
\hline
\end{tabular}

\section{Independent Group T-Test Results to Determine Whether Self-Esteem and Perfectionism Differ or Not Differ According to Gender Variable}

Self-esteem and perfectionist levels of academicians show normal distribution on gender at the level of .05 significance. In order to determine whether Self-Esteem and perfectionism scores differ according to gender variable, independent group t-test results are presented in Table 3.

Table 3.

Independent Group T-Test Results to Determine Whether Self-Esteem and Perfectionism Differ or not Differ According to Gender Variable

\begin{tabular}{llllllll}
\hline Variables & Groups & Mean & $\mathrm{S}$ & \multicolumn{4}{c}{$\mathrm{t}$-Test } \\
& & & $\mathrm{t}$ & $\mathrm{Sd}$ & $\mathrm{p}$ \\
\hline Self-Esteem & Woman & 17.90 & 1,75 & .643 & .29 & .521 \\
& Man & 17.71 & 1.48 & & & \\
Perfectionism & Woman & 92.7 & 16.85 & -2.92 & 3.22 & .004 \\
& Man & 102.1 & 18.93 & & & \\
\hline
\end{tabular}

As can be seen in Table 3, there was a significant difference between the perfectionism scores of women and men in the study. The significance value $(\mathrm{p}=, 004)$ resulting from the independent sample t-test appears to be $\mathrm{p}<.05$. It was revealed that there was no significant difference between self-esteem scores. The significance value $(p=521)$ resulting from the independent sample t-test appears to be $p>, 05$. 
Independent Group T-Test Results to Determine Whether Self-Esteem and Perfectionism Scores Differ or Not Differ According to Age Variable

Since self-esteem and perfectionist levels of academicians are normally distributed at the level of .05 significance, ANOVA test was conducted to determine whether self-esteem and perfectionism scores differ or not differ according to age variable, and the results are presented in Tables 4 and 6. The self-esteem scores of the academicians are given in Table 4. Descriptive statistics and ANOVA results are given in Table 5 by age ranges.

Table 4

Descriptive Statistics of Self-Esteem Points

\begin{tabular}{lccc}
\hline Ages & N & Mean & $\begin{array}{c}\text { Standart Deviation } \\
(\mathrm{Sd})\end{array}$ \\
\hline 18-30 years & 17 & 17.35 & .39 \\
$31-45$ years & 83 & 17.79 & .18 \\
$46-65$ years & 25 & 18.24 & .31 \\
\hline
\end{tabular}

Table 5

ANOVA Results According to Age Variable of Self-Esteem Points

\begin{tabular}{llcccl}
\hline $\begin{array}{l}\text { Source of } \\
\text { variance }\end{array}$ & $\begin{array}{l}\text { Sum of } \\
\text { squares }\end{array}$ & Sd & $\begin{array}{c}\text { Average of } \\
\text { squares }\end{array}$ & $\mathrm{F}$ & $\mathrm{p}$ \\
\hline $\begin{array}{l}\text { Between } \\
\text { groups }\end{array}$ & 8.168 & 2 & 4.084 & 1.519 & .223 \\
Within groups & 327.96 & 122 & 2.688 & & \\
Total & 336.128 & 124 & & & \\
\hline
\end{tabular}

Self-esteem of academicians does not change significantly depending on age $F(2,122)=$ $1.519 \mathrm{p}>$.05. In Table 6, the perfectionism scores of academicians are presented with descriptive statistics and ANOVA results are given in Table 7 by age ranges. 
Table 6

Descriptive Statistics of Perfectionism Points

\begin{tabular}{llll}
\hline Ages & $\mathrm{N}$ & Mean & $\mathrm{Sd}$ \\
\hline $18-30$ years & 17 & 92.23 & 11.26 \\
$31-45$ years & 83 & 97.27 & 19.44 \\
$46-65$ years & 25 & 97.48 & 18.28 \\
\hline
\end{tabular}

Table 7

ANOVA Results of Perfectionism Scores by Age Variable

\begin{tabular}{llcccc}
\hline $\begin{array}{l}\text { Source of } \\
\text { variance }\end{array}$ & $\begin{array}{l}\text { Sum of } \\
\text { squares }\end{array}$ & Sd & $\begin{array}{c}\text { Average of } \\
\text { squares }\end{array}$ & $\mathrm{F}$ & $\mathrm{p}$ \\
\hline Between groups & 381.14 & 2 & 190.57 & .566 & .569 \\
Within groups & 41043.92 & 122 & 336.42 & & \\
Total & 41425.072 & 124 & & & \\
\hline
\end{tabular}

Evaluation of Academicians' Self-Esteem and Perfectionism Levels by Academic Title, Faculty Name and Duration of Study

In order to determine whether there is a difference between academic self-esteem levels and perfectionism, academic title, faculty name and working time was evaluated and the academic title was evaluated using the Kuruskal Wallis test since the faculty name and working time did not show normal distribution. Kuruskal Wallis test results of the academics, which vary according to the faculties, from the self-esteem scale are given in Table 8.

Table 8

Kuruskal Wallis Test Results of the Relationship Between Self-Esteem and Faculties

\begin{tabular}{lccccc}
\hline Groups & $\mathrm{N}$ & Mean & $\mathrm{X}^{2}$ & $\mathrm{sd}$ & $\mathrm{p}$ \\
\hline Faculty of Education & 45 & 59.99 & 21.81 & 10 & .016 \\
Faculty of Law & 4 & 51.75 & & & \\
Faculty of Science and Literature & 3 & 40.67 & & & \\
Faculty of Architecture & 7 & 48.79 & & & \\
Engineering Faculty & 9 & 68.33 & & & \\
\hline
\end{tabular}




\begin{tabular}{lll}
\hline Faculty of Health Sciences & 27 & 52.37 \\
Communication faculty & 6 & 76.33 \\
$\begin{array}{l}\text { Faculty of Economics and Administrative } \\
\text { Sciences }\end{array}$ & 12 & 102.38 \\
Faculty of Agriculture & 7 & 66.80 \\
Faculty of Theology & 5 & 60.10 \\
\hline
\end{tabular}

The results of the analysis show that the scores that academicians got from the self-esteem scale differed significantly according to the faculties, $X 2(s d=10, n=125$, $)=21.81, p<.05$. This finding shows that faculties have different effects on self-esteem. Considering the rank averages, it is seen that the Faculty of Economics and Administrative Sciences has the highest self-esteem.

Considering the working time at the university, it shows that the scores obtained by academicians from the self-esteem scale differ significantly according to their working time, $\mathrm{X} 2(\mathrm{sd}=3, \mathrm{n}=125)=10.01,, \mathrm{p}<.05$. This finding shows that working time at university has different effects on self-esteem. Considering the rank averages, it is seen that academicians with the highest 21 to 35 years of working time have self-esteem.

It is seen that the scores of academicians working at the university from the self-esteem scale do not differ significantly according to their academic titles, $\mathrm{X} 2(\mathrm{sd}=3, \mathrm{n}=125$,) $=$ 7.57, $\mathrm{p}>.05$. This finding shows that academic titles at the university have no different effects on self-esteem.

When we look at the academic titles and faculties at the university regarding the perfectionism levels of academicians, the working time is X2 ( $\mathrm{sd}=3, \mathrm{n}=125,)=13.04, \mathrm{p}$ $=.05$ and academic title $\mathrm{X} 2(\mathrm{sd}=3, \mathrm{n}=125$, $)=$ While 16.64 was observed to differ significantly according to $\mathrm{p}<.05$, it was found that faculties did not differ according to X2 $(s d=10, n=125)=17.43,, p>.05$. Considering the average of working hours, it is seen that academicians who have 6 to 11 years of working time have perfectionism characteristics. When the academic title is analyzed, it is seen that the average of academicians with a doctorate is higher than the academicians who have the other titles.

\section{RESULT, DISCUSSION AND SUGGESTIONS}

\section{Results}

It was revealed that $58 \%$ of the participants in the study were female and $42 \%$ were male. It turned out that $52 \%$ of them were married, $45 \%$ of them were single and $43 \%$ of them were Assistant Professors. $36 \%$ of the academics who participated in this study are from Education Faculties and 22\% of them were from the Faculty of Health Sciences. It was found that $43 \%$ of the participants have been working as academic staff for 1 to 5 years. 
$66 \%$ of the academicians who participated in the study were determined to be between 31 and 45 years old.

In this study, the relationship between self-esteem and perfectionism levels of academics was investigated; It turned out that there was no significant relationship between them. It has been examined whether there is a differentiation with the self-esteem and perfectionism levels of academicians, age, gender, faculty and working time, and it has been revealed that self-esteem and working time and faculty differ significantly in terms of gender, age and academic title. It is observed that self-esteem increases as the working time increases, and academics working in the faculty of economics and administrative sciences also have high self-esteem. It was also revealed that academicians' level of excellence was significantly different in terms of gender, academic title, and age and faculty variables. It is seen that academicians, whose working period is between 6-11 years, have high perfectionism, and academicians with a PhD title are more perfectionist. It is seen that the level of perfectionist differs according to the age variable, while the level of self-esteem does not differ.

\section{Discussion}

It is known that the relationship between self-esteem and perfectionism levels of academics is actually a subject that needs to be investigated. In particular, studies show that self-esteem, social anxiety and conflict style are among the dimensions to be examined in the perfectionism procedure (Noga, 1994). In short, it can be stated that perfectionism and self-esteem need to be examined in an integral whole.

The findings of this study reveal that there is no relationship between self-esteem and perfectionist levels of academicians. This finding contradicts with Ashby and Rice's study (2002). According to Ashby and Rice, it can be said that there is a meaningful relationship between them. It can be thought that these different results may also originate from cultural differences. In the literature review, which is stated to be a part of perfectionism self-identity (Frost, Marten, Lahart \& Rosenblate, 1990: Hewitt \& Flett, 1991: Slaney \& Johnson, 1992), academicians are expected to have a relationship between self-self and perfectionism. Rice, Ashby and Slaney (1998) reported that there was a significant interaction between self-esteem and incompatible perfectionism.

The differentiation of academicians' working time at self-esteem and perfectionism levels is parallel. It is seen that when academicians have a long working period, they differ with self-esteem and those with less working time differ with perfectionism. In this case, it can be said that as the experience increases, self-esteem increases. It can be said that individuals excited their motivation to be proficient in their profession, their desire to show themselves and their perfection, especially in the first years of their working life.

\section{Suggestions}

When literature review is conducted during the research, it can be said that there are studies in these areas, whether perfectionism or self-esteem. However, it is seen that the sample of these studies generally consists of primary, secondary and university students. The intensity of the studies, which are identified by the parental attitudes, especially on 
the level of perfectionism, is remarkable. However, it turns out that there is not much work done as an example of adults.

In short, it is thought that doing the same research with different sample groups consisting of adults may be more beneficial in order to better understand perfectionist personality structure and self-esteem.

In particular, evaluating the perfectionism measurement tool in line with its subdimensions may be among the suggestions. In order to increase the strengths of such studies, it is important to be able to do it from a multi-dimensional perspective. In short, it is thought that it can be supported with different psychological or personality tests.

\section{References}

Abbasoğlu, E., \& Öncü, E. (2013). Beden eğitimi öğretmeni adaylarının benlik saygıları ve öğretmenlik mesleğine yönelik tutumları [Pre-Service Physical Education Teachers' SelfEsteems and Attitudes toward Teaching Profession]. Ahi Evran Üniversitesi Kırşehir Eğitim Fakültesi Dergisi (KEFAD) [Journal of Ahi Evran University Kırşehir Faculty of Education], 14(2), 407-425.

Ashby, J., \& Rice, K. G. (2002). Perfectionism, dysfunctional attitudes, and self-esteem: A structural equations analysis. Journal of Counselling and Development, 80(2), 197-203.

Aslan, A. G. D., \& Akyol, A. K. (2006). Okul öncesi öğretmen adaylarının öğretmenlik mesleğine yönelik tutumları ve mesleki benlik saygılarının incelenmesi [Investigation of pre-school teacher candidates' attitudes towards teaching profession and professional self-esteem]. Çukurova Üniversitesi Sosyal Bilimler Enstitüsü Dergisi, [Journal of Çukurova University Institute of Social Sciences], 15(2), 51-60.

Bieling, P. J., Israeli, A., Smith, J., \& Antony, M. M. (2003). Making the grade: The behavioral consequences of perfectionism in the classroom. Personality and Individual Differences, 35, 163-178.

Bursal, M. (2017). SPSS ile temel veri analizleri [Basic data analysis with SPSS]. Ankara: Anı Yayıncılık.

Büyüköztürk, Ş., Çakmak, E. K., Akgün, Ö. E., Karadeniz, Ş., \& Demirel, F. (2017). Bilimsel araştırma yöntemleri (Scientific research methods). Ankara: Pegem Akademi (Pegem Academy).

Cırcır, B. (2006). Öğretmen adaylarının denetim odakları ve mükemmelliyetçilik tutumlarının bazı özlük niteliklerine göre karşılaştırmalı olarak incelenmesi (Comparative examination of preservice teachers' locus of control and perfectionism attitudes according to some personal qualities) (Master's Thesis). Retrieved from Turkish Council of Higher Education thesis database (ID: 189381).

Flett, G. L., Hewitt, P. L., Blankstein, K. R., \& Gray, L. (1998). Psychological distress and the frequency of perfectionistic thinking. Journal of Personality and Social Psychology, 75, 1363-1381.

Frost, R. O., Marten, P., Lahart, C., \& Rosenblate, R. (1990). The dimensions of perfectionism. Cognitive Therapy and Research, 14, 449-468. 
Hamachek, D. E. (1978). Psychodynamics of normal and neurotic perfectionism. Psychology, 15, 2733.

Hewitt, P. L., \& Flett, G. L. (1991), Perfectionism in the self and social contexts: conceptualization, assessment, and association with psychopathology. Journal of Personality and Social Psychology, 60, 465-470.

Karasar, N. (2002). Bilimsel araştırma yöntemi (Scientific research method ) (11. basım.). Ankara: Nobel Yayınları.

Kassin, S. (1998). Psychology (Second Edition). New Jersey: Prentice Hall.

Korkmaz, M. (1996). Yetişkin örneklem için bir benlik saygısı ölçeğinin güvenirlik ve geçerlik çalışması (Reliability and validity study of a self-esteem scale for an adult sample) (Master's Thesis). Retrieved from Turkish Council of Higher Education thesis database (ID: 52350).

Leory, M. R. (1996). Self-presentation, impression, management and interpersonal behavior. New York: Harper Collins Publishers.

Noga, L. (1994). An examination of perfectionism and its relationship to self-esteem, social anxiety, and conflict mode, university of Alberta. Erişim adresi: https://era.library.ualberta.ca/items/d523439f-2b04-4cac-979b4d82f3f5eeca/view/7e0c696f-ae06-4959-85e9-7ad10659b9f1/MM82109.pdf

Rice, K. G., Ashby, J., \& Slaney, R. B. (1998). Self-esteem as a mediator between perfectionism and depression: A structural equations analysis. Journal of Counseling Psychology, 45(3), 304314.

Rosenberg, M. (1965). Society and the adolescent self-image. Princeton, NJ: Princeton University Press.

Salami, S. O. (2010). Moderating effects of resilience, self-esteem and social support on adolescents' reactions to violence. Asian Social Science, 6(12), 101-110.

Sapmaz, F. (2006). Üniversite öğrencilerinin uyumlu ve uyumsuz mükemmeliyetçilik özelliklerinin psikolojik belirti düzeyleri açisindan incelenmesi (Examining the harmonious and incompatible perfectionism characteristics of university students in terms of their psychological symptom levels )(Master's Thesis). Retrieved from Turkish Council of Higher Education thesis database (ID: 186635).

Slaney, R. B., Rice, G. K., Mobley, M., Trippi, J., \& Ashby, J. (2001). The revised almost perfect scale. Measurement and Evaluation in Counselling and Development, 34, 130-144.

Slaney, R. B., \& Ashby, J. (1996). Perfectionists: Study of a criterion group. Journal of Counselling and Development, 74 (4), 393-398.

Tuncer, B., \& Voltan-Acar, N. (2006). Kaygı düzeyleri farklı üniversite hazırlık sınıfı öğrencilerinin mükemmeliyetçilik özelliklerinin incelenmesi (Examining the perfectionism characteristics of university preparatory class students with different anxiety levels). Kriz Dergisi,( Jurnal of Crisis) 14(2), 1-15.

Yelsma, P., \& Yelsma, J. (1998). Self-esteem and social respect with in the high school. Journal of Social Psychogy. 138(4), 431-441. 
In the writing process of the study titled "A Study to Investigate the Relationship between the Perfectionist Level and Self -Esteem Level of Academicians Working at Universities”, the rules of scientific, ethical and citation were followed; it was undertaken by the authors of this study that no falsification was made on the collected data. "Sakarya University Journal of Education Journal and Editor" had no responsibility for all ethical violations to be encountered, and all responsibility belongs to the authors and that the study was not submitted for evaluation to any other academic publishing environment. 